\title{
Retracted: Measuring the critical effect of marketing mix on customer loyalty through customer satisfaction in food and beverage products
}

\author{
Suci Ayu Sudari ${ }^{a^{*}}$, Arun Kumar Tarofder ${ }^{\mathrm{b}}$, Ali Khatibi ${ }^{\mathrm{a}}$ and Jacquline Tham ${ }^{\mathrm{a}}$ \\ ${ }^{a}$ Post Graduate Centre, Management and Science University, University Drive, Off Persiaran Olahraga, Section 13, 40100, Selangor, \\ Malaysia \\ ${ }^{b}$ Faculty of Business Management and Professional Studies, Management and Science University, University Drive, Off Persiaran \\ Olahraga, Section 13, 40100, Selangor, Malaysia

\section{H R O N I C L E} \\ Article history: \\ Received: April 15, 2019 \\ Received in revised format: April \\ 272019 \\ Accepted: May 11, 2019 \\ Available online: \\ May 12, 2019 \\ Keywords: \\ Marketing Mix (4Ps) \\ Customer Satisfaction \\ Customer Loyalty \\ Small and Medium Enterprises

\section{A B S T R A C T} \\ The purpose of this paper is to analyze the effect of marketing mix on customer loyalty through \\ customer satisfaction in food and beverage products of SMEs in Malaysia. The method of collecting \\ data is by using questionnaire and a sample of 300 customers is used for data gathering. Path anal- \\ ysis and Sobel test are used in analyzing the data. The finding shows that product, promotion, place \\ and price have positive effects on customer satisfaction of food and beverage products SMEs in \\ Malaysia. Product, promotion, place and price give contribution to customer satisfaction about \\ $68.9 \%$ while the rest is affected by other variables which are not included in this research. Moreo- \\ ver, customer satisfaction has a positive effect on customer loyalty. The finding also shows that \\ product, promotion, place and price had positive effects on customer loyalty through customer sat- \\ isfaction of food and beverage products SMEs in Malaysia. Product, promotion, place, price and \\ customer satisfaction influence on customer loyalty about $61.7 \%$.
}

C 2019 by the authors; licensee Growing Science, Canada

\section{Introduction}

In this era, information technology is developing rapidly which makes competition tighter. Companies should arrange marketing mix well in order to be able to attract customers and create customer loyalty. Indeed, marketing mix is one of the factors influencing customer satisfaction and loyalty. According to Harsono (2017) "By having a good product (Product), reasonable price (Price), accessible location (Place) and effective promotion strategy (Promotion) companies will have the ability to influence consumers to learn and purchase their product, thus increasing the chance of creating a loyal customer". Small Medium Enterprises (SMEs) play an important role in developing countries. Department of Statistic Malaysia (2017) show that SMEs contributed about 37.1\% for the Growth Domestic Product (GDP) rate in Malaysia. These percentages of contribution were still at a low rate where SMEs in Malaysia has the targets which set in the SME Master plan. According to Department of Statistic Malaysia (2017), the sales value of food and beverage at SMEs in last month decreased significantly. The contribution of manufacturing sector for GDP also was lower than the others sector, the contribution was only about 34.6\%. Dianai-Rose et al. (2016) in the research of food and beverage product of SMEs in Malaysia showed that there were some customers who did not purchase the SMEs products, but in fact customers

* Corresponding author.

E-mail address: suciayusudari@gmail.com (S. A. Sudari) 
noticed the products. SMEs' products cover local products, while customer's preference is on imported products. It can be said that customers would not feel satisfy with local products and prefer to purchase imported products. Ahmad (2007) and Mohd. Shariff et al. (2016) also stated that local entrepreneurs are less sensitive towards new existing issues and tend to be followers rather than innovators. In addition, there is a competition between local food and imported food where customers perceive that the quality of local food is still low.

\section{Literature Review}

\subsection{Marketing Mix (4Ps)}

Marketing activity is the basis of business activities where a company can get sales revenue and profit from marketing activities. Marketing activities consist of marketing mix which includes a set of relevant solutions which enable customers to reach the (national) requirements and achieve the companies' objectives. Marketing mix can be also described as a set of controllable marketing features where a firm applies to reach a desired response on the targeted market called as 4P's, i.e. Marketing, being Product, Price, Promotion and Place and these elements will end up to customer satisfaction and loyalty (Wahab et al., 2015).

\subsection{Product}

Verma and Singh (2017) as cited in Išoraite (2016) defined product "as a physical product or service to the consumer for which consumer is willing to pay. This includes half of the material goods, such as furniture, clothing, and grocery items and intangible products namely services which users buy". The products are created by company to fulfill customer needs and wants. These days, most companies must create products which are appropriate for customers' needs by offering innovative products.

\subsection{Promotion}

Išoraite (2016) quoted that "the promotion of the marketing mix is a tool that helps disseminate information, encourage the purchase and affects the purchase decision process". Promotion is an activity in offering, selling, and recognizing the products to the consumers. Promotion must be attractive and can encourage the consumers to buy and consume the products as always.

\subsection{Place}

Pordehghan (2015) pointed out that "distribution refers to activities that are done to deliver a product or service to customers. Distribution and place are the simplest terms in 4P; however, they play a very important role in it". Distribution or place in marketing activity is the activity in delivering products to the consumers, which also can be said that place helps the consumers reach or find the products. Companies need to manage the strategies location as well where consumers can find the products easily (Paniandi et al., 2018).

\subsection{Price}

Išoraite (2016) argued that "price is perceived as the only element of the marketing mix, generating revenue and the most important customer satisfaction and loyalty factor". Price can be described as exchange value of the product. Price is the primary criterion for product evaluation and any firm should have price management strategy. Besides offering competitive price, firms must match the price with the quality and quantity of the products. Price also can create the customer satisfaction and customer loyalty as well.

\subsection{Customer Satisfaction}

Customer satisfaction is the key success factor for business entity (Adikaram \& Khatibi, 2016). According to Kotler and Keller (2009) and Kotler et al. (2010) "a person's feelings of pleasure or disappointment that result from comparing a product perceived performance (or outcome) to expectations". Khadka and 
Maharjan (2017) pointed out that customer satisfaction is dynamic and relative. In improving customer satisfaction, customer expectations should be noticed and it can be concluded that customer satisfaction is consumer's feeling about the performance of the product where consumers have expectation about the products and feel satisfy if the performance of the product exceeds consumer's expectations. Customer satisfaction has six basic approach theories from experts. Isac and Rusu (2014) provided some approach theories of customer satisfaction such as assimilation theory, contrast theory, assimilation contrast theory, negativity theory, hypothesis testing theory, and disconfirmation theory. Disconfirmation theory is associated with this research where the theory explains about customers' expectations from the products. The expectations can be about standard of quality compared with the performance of products or the real quality of products. Then customers evaluate the products whether that makes customers feel satisfy or dissatisfy.

\subsection{Customer Loyalty}

Customer loyalty is described as the repurchasing behavior and customers' positive feedback towards the company which provides excellent products and services. Khadka and Maharjan (2017) explained that the expenses to gain a new customer is much more than retaining the existing one. Loyal customers will encourage the others to buy the products while loyal customers will think twice to buy another product offered by another company. Furthermore, loyalty can support customer preferences and reactions to products and services well (Albattat \& Romli, 2017). Customer loyalty also makes repeat purchases more and will generate higher income for the company. Thus, customer loyalty is the customer's behavior who always doing repeat purchase for the products of the company after evaluating the products and feeling satisfy about that (Salem \& Chaichi, 2018).

\section{Research Methodology}

This study used Likert scale 1-5 measurement of questionnaire and distributed 300 customers of food and beverage products SMEs in Malaysia. For sampling process, this research uses non probability sampling with convenience sampling. The sample size uses rules of thumb. This study also conducted validity and reliability test to ensure the validity and reliability of the questionnaire. To test the model, this study used the path analysis approach, and SPSS 20.0 was used to analyze the data. There are several test equipment that has been done in classic assumption test in this research such as normality test, multicollinearity test, and heteroscedasticity test.

\subsection{Conceptual Framework and Hypotheses Development}

Fig. 1 demonstrates the structure of the proposed study of this paper.

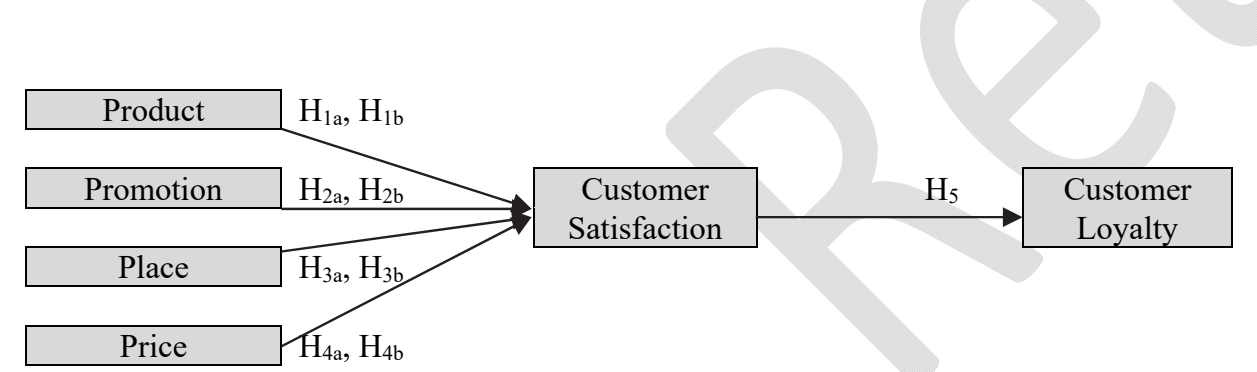

Fig. 1. Conceptual Framework

\subsubsection{The Linkage between Product and Customer Satisfaction}

Products quality brings satisfaction and enhances competitive advantage and attracts the potential customers (Nuseir \& Madanat, 2015). By products marketing mix variable, we mean the ideas such as innovative services and added value services in a company (Alipour et al., 2018). Customers became satisfied by experiencing the quality (Al Muala \& Al Qurneh, 2012). According to Sukamto and Lumintan (2015), 
increasing in marketing mix namely product will significantly increase customer satisfaction. The previous studies also show that product had a positive effect on customer satisfaction (Kadhim et al., 2016; Bawa et al., 2013; Mustawadjuhaefa et al., 2017).

$\mathrm{H}_{1 \mathrm{a}}$ : Product has a positive effect on customer satisfaction of food and beverage products of SMEs in Malaysia.

\subsubsection{The Linkage between Promotion and Customer Satisfaction}

Promotion is an activity that introduces and highlights the products or services to customers (Nuseir \& Madanat, 2015). The promotion activity should be honest, information based on truthfulness, transparency, and full sincerity for helping in increasing customer satisfaction (Niharika, 2015). The researches that have been conducted by researchers also show the linkage between promotion and customer satisfaction (Kadhim et al., 2016; Bawa et al., 2013; Alipour et al., 2018; Wahab et al., 2016; Verma and Singh, 2017)

$\mathrm{H}_{2 \mathrm{a}}$ : Promotion has a positive effect on customer satisfaction of food and beverage products of SMEs in Malaysia.

\subsubsection{The Linkage between Place and Customer Satisfaction}

Organizational supply chains, including suppliers, manufacturers, wholesalers, retailers, and end users, secure competitive positions, ultimately increasing company ability to satisfy customers more efficiently (Nuseir \& Madanat, 2015). Inconvenience location for the customers lead to dissatisfaction among the customers which further influence the organization in negative way (Niharika, 2015). Services offered to customers are an important basis to obtain customer satisfaction. Those statements were supported by the previous researches (Kadhim et al., 2016; Bawa et al., 2013; Alipour et al., 2018; Wahab et al., 2016).

$\mathrm{H}_{3 \mathrm{a}}$ : Place has a positive effect on customer satisfaction of food and beverage products of SMEs in Malaysia.

\subsubsection{The Linkage between Price and Customer Satisfaction}

Price becomes crucial factor towards customer responses of product values (Nuseir \& Madanat, 2015). Usually customers feel satisfy if quality of the products exceeds costs that spent by customers. Any researches described that there is relationship between price and customer satisfaction (Kadhim et al., 2016; Bawa and Shameem; 2015; Alipour and Pour et al, 2018).

$\mathrm{H}_{4 a}$ : Price has a positive effect on customer satisfaction of food and beverage products SMEs in Malaysia.

\subsubsection{The Linkage between Product, Customer Satisfaction and Customer Loyalty}

Product quality has the greatest impact on the level of satisfaction that ignites a sense of loyalty to customers. Product which has good brand also leads to customer satisfaction. The increase in customer satisfaction also increases customer loyalty (Nuseir \& Madanat, 2015). Nikhashemi et al. (2017) argued that customers who feel satisfy with the quality of products never switch to another products. These statements are supported by the previous studies which show that product has a positive effect on customer satisfaction and reflects to customer loyalty (Muala \& Qurneh, 2012; Wahab et al., 2016; Sukamto \& Lumintan, 2015).

$\mathrm{H}_{1 \mathrm{~b}}$ : Product has a positive effect on customer loyalty through customer satisfaction of food and beverage products of SMEs in Malaysia.

\subsubsection{The Linkage among Promotion, Customer Satisfaction and Customer Loyalty}

Promotion aims to establish relationship with customers to inform customers or affect customers' attitude (Pourdehghan, 2015). Attractive promotion can bring customers being interested in the offered products. The promotion which is appropriate or even exceed with the real quality of product offered can make 
customers fell satisfy and customers will be loyal to the company. Promotion has a positive effect on customer satisfaction and customer loyalty (Verma \& Singh, 2017; Mustawadjuhaefa et al., 2017; Sukamto \& Lumintan, 2015).

$\mathrm{H}_{2 \mathrm{~b}}$ : Promotion has a positive effect on customer loyalty through customer satisfaction of food and beverage products of SMEs in Malaysia.

\subsubsection{The Linkage among Place, Customer Satisfaction and Customer Loyalty}

Place is one of marketing mix elements that is directly linked to customer loyalty (Nuseir \& Madanat, 2015). According to Pourdehghan (2015) "Good store-image not only attracts more attention, interests, and contacts from potential consumers that also increases consumer satisfaction and positive word-tomouth". Place has positive and significant impact on customer satisfaction and customer loyalty (Al Muala \& Al Qurneh, 2012; Wahab et al., 2016; Verma \& Singh, 2017).

$\mathrm{H}_{3 \mathrm{~b}}$ : Place has a positive effect on customer loyalty through customer satisfaction of food and beverage products SMEs in Malaysia.

\subsubsection{The Linkage among Price, Customer Satisfaction and Customer Loyalty}

Price is very important for customers and for companies because the pricing of a product affects customer satisfaction and customer loyalty. The company intends to get adequate profits but at the same time, the company does not intend to lose customers because of the higher prices (Auh and Johnson, 2005). Customers who feel satisfy are willing to spend more but not compromise on products' quality standards (Nuseir \& Madanat, 2015). This means price can influence the level of satisfaction among customers and that satisfaction brings loyalty (Al Muala \& Al Qurneh, 2012; Wahab et al., 2016; Sukamto \& Lumintan, 2015).

$\mathrm{H}_{4 \mathrm{~b}}$ : Price has a positive effect on customer loyalty through customer satisfaction of food and beverage products of SMEs in Malaysia.

\subsubsection{The Linkage between Customer Satisfaction and Customer Loyalty}

Every satisfied customer is supposed to spread the positive word of mouth to other people. Furthermore, satisfaction is the main driver of loyalty and for that customer must be highly satisfied (Khadka \& Maharjan, 2017). Customer satisfaction measures customer feelings and expectations while customer loyalty reflects purchasing behavior and future purchase commitments. More specifically, customer satisfaction provides a basis for achieving customer loyalty. Some studies show that customer satisfaction has significant impact on customer loyalty (Awan \& Rehman, 2014, Iqbal \& Shah; 2016, Ganiyu, 2017, Nguyen et al.; 2018).

$\mathrm{H}_{5}$ : Customer satisfaction has a positive effect on customer loyalty of food and beverage products of SMEs in Malaysia.

\section{Result}

\subsection{Demographic Profile}

Table 1 presents the summary of the personal characteristics on the participants in this survey. As we can observe from the results, $40 \%$ of the participants were male while $60 \%$ of them were female. In terms of age, $76 \%$ of the participants were young people aged less than 25 years. Moreover, most of the participants were students and single. Other information are presented in Table 1 as follows, 
Table 1

Demographic Profile of Respondents

\begin{tabular}{|c|c|c|c|}
\hline Demographic & Options & Frequency & Percentage \\
\hline \multirow{3}{*}{ Gender } & Male & 120 & $40 \%$ \\
\hline & Female & 180 & $60 \%$ \\
\hline & Total & 300 & $100 \%$ \\
\hline \multirow{6}{*}{ Age } & $<25$ & 229 & $76.3 \%$ \\
\hline & $26-35$ & 45 & $15 \%$ \\
\hline & $36-45$ & 18 & $6 \%$ \\
\hline & $46-55$ & 6 & $2 \%$ \\
\hline & $>56$ & 2 & $0.7 \%$ \\
\hline & Total & 300 & $100 \%$ \\
\hline \multirow{12}{*}{ Occupation } & Student & 205 & $68.3 \%$ \\
\hline & Entrepreneur & 15 & $5 \%$ \\
\hline & Educator & 20 & $6.7 \%$ \\
\hline & Staff & 31 & $10.3 \%$ \\
\hline & Engineer & 5 & $1.7 \%$ \\
\hline & Others & 24 & $8 \%$ \\
\hline & Total & 300 & $100 \%$ \\
\hline & Malay & 171 & $57 \%$ \\
\hline & Indian & 78 & $26 \%$ \\
\hline & Chinese & 18 & $6 \%$ \\
\hline & Others & 33 & $11 \%$ \\
\hline & Total & 300 & $100 \%$ \\
\hline \multirow{5}{*}{ Education } & High School Degree & 104 & $34.7 \%$ \\
\hline & Bachelor & 157 & $52.3 \%$ \\
\hline & Master & 34 & $11.3 \%$ \\
\hline & Phd & 5 & $1.7 \%$ \\
\hline & Total & 300 & $100 \%$ \\
\hline \multirow{3}{*}{ Marital Status } & Single & 263 & $87.7 \%$ \\
\hline & Married & 37 & $12.3 \%$ \\
\hline & Total & 300 & $100 \%$ \\
\hline \multirow{5}{*}{ Family Size } & 0 children & 269 & $89.7 \%$ \\
\hline & 1 child & 13 & $4.3 \%$ \\
\hline & 2 children & 8 & $2.7 \%$ \\
\hline & $>2$ children & 10 & $3.3 \%$ \\
\hline & Total & 300 & $100 \%$ \\
\hline \multirow{3}{*}{$\begin{array}{l}\text { Ever Tasted Local Food and Beverage of SM } \\
\text { Es in } \\
\text { Malaysia }\end{array}$} & Yes & 300 & $100 \%$ \\
\hline & No & 0 & $0 \%$ \\
\hline & Total & 300 & $100 \%$ \\
\hline \multirow{6}{*}{$\begin{array}{l}\text { Kind of Local Food and Beverage of SMEs in } \\
\text { Malaysia that Customers Tasted mostly }\end{array}$} & Snack food & 116 & $38.7 \%$ \\
\hline & Coffee & 55 & $18.3 \%$ \\
\hline & Chocolate & 48 & $16 \%$ \\
\hline & Traditional food & 53 & $17.7 \%$ \\
\hline & Others & 28 & $9.3 \%$ \\
\hline & Total & 300 & $100 \%$ \\
\hline
\end{tabular}




\subsection{Descriptive Analysis}

Descriptive analysis is used to analyze and learn about variables in this study which is obtained from respondents' response. The average score for product is 3.43 , promotion is 3.16 , place is 3.34 , price is 3.22 , customer satisfaction is 3.26 , and customer loyalty is 3.18 .

\subsection{Hypothesis Test}

\subsubsection{Hypotheses test for direct effect}

Hypothesis test in this research is measured based on significant value. Here the hypothesis test is for direct effect. As shown on Table 2, significant value of all independent variables is under 0.05, which means the hypotheses are accepted.

\section{Table 2}

Hypotheses Test of the Direct Effect

\begin{tabular}{lcc}
\multicolumn{1}{c}{ Hypothesis } & Significant Value & Notes \\
\hline Product has a positive effect on customer satisfaction (H1a) & 0.000 & Accepted \\
Promotion has a positive effect on customer satisfaction (H2a) & 0.000 & Accepted \\
Place has a positive effect on customer satisfaction (H3a) & 0.000 & Accepted \\
Price has a positive effect on customer satisfaction (H4a) & 0.000 & Accepted \\
Customer satisfaction has a positive effect on customer loyalty (H5) & 0.019 & Accepted \\
\hline
\end{tabular}

Source: primary data processed, 2018

\subsubsection{Hypothesis test of indirect effect}

Hypothesis test for indirect effect uses Sobel test. Sobel test is conducted to analyze whether there is a mediation variable between independent variables and dependent variable or not. Hypothesis is accepted if the calculation of Sobel test ( $\mathrm{z}$ value) is higher 1.96. Moreover, to calculate $\mathrm{z}$ value conducts this formula below:

$$
\mathrm{Z}=\frac{a b}{S a b} \text { where } \quad \mathrm{Sab}=\sqrt{b^{2} S a^{2}+a^{2} S b^{2}+S a^{2} S b^{2}}
$$

where:

a $\quad=$ regression coefficient that represents effect of $\mathrm{X}$ toward $\mathrm{Y}$

$\mathrm{b} \quad=$ regression coefficient that represents effect of $\mathrm{Y}$ toward $\mathrm{Z}$

$\mathrm{Sa}=$ standard error of a

$\mathrm{Sb} \quad=$ standard error of $\mathrm{b}$

According to the results of Table 3, all hypotheses are accepted.

\section{Table 3}

Hypothesis Test of Indirect Effect

\begin{tabular}{lcc}
\multicolumn{1}{c}{ Hypotheses } & Z Value & Notes \\
\hline Product has a positive effect on customer loyalty through customer satisfaction (H1b) & 2.027401896 & Accepted \\
Promotion has a positive effect on customer loyalty through customer satisfaction (H2b) & 2.084260908 & Accepted \\
Place has a positive effect on customer loyalty through customer satisfaction (H3b) & 2.1277111 & Accepted \\
Price has a positive effect on customer loyalty through customer satisfaction (H4b) & 2.238417137 & Accepted \\
\hline
\end{tabular}

Source: primary data processed, 2018

\subsection{Path Analysis}

\subsubsection{Analysis of Structural Model 1}

Analysis of structural model 1 aims to determine the effect of products, promotion, place, and price toward customer satisfaction. 
Table 4

The results of analyzing the first model

\begin{tabular}{|c|c|c|c|c|c|}
\hline \multirow[t]{2}{*}{ Model 1} & \multicolumn{2}{|c|}{$\begin{array}{c}\text { Unstandardized } \\
\text { Coefficients }\end{array}$} & \multirow{2}{*}{$\begin{array}{c}\text { Standardized } \\
\text { Coefficients } \\
\text { Beta }\end{array}$} & \multirow[b]{2}{*}{$\mathrm{t}$} & \multirow[b]{2}{*}{ Sig. } \\
\hline & $\mathrm{B}$ & Std. Error & & & \\
\hline Intercept & .603 & 1.047 & & .576 & .565 \\
\hline Product & .177 & .042 & .185 & 4.242 & .000 \\
\hline Promotion & .207 & .044 & .224 & 4.741 & .000 \\
\hline Place & .202 & .039 & .225 & 5.132 & .000 \\
\hline Price & .325 & .045 & .351 & 7.202 & .000 \\
\hline
\end{tabular}

Source: Output of SPSS 20.0

Based on the results of Table 4, the structural model 1 of path analysis can be written as follows:

$\mathrm{Y}=0.185 \mathrm{X}_{1}+0.224 \mathrm{X}_{2}+0.225 \mathrm{X}_{3}+0.351 \mathrm{X}_{4}+\mathrm{e} 1$

\section{Table 5}

Determination Coefficient 1

\begin{tabular}{lcccc}
\hline Model & $\mathrm{R}$ & $\mathrm{R}^{2}$ & Adjusted $\mathrm{R}^{2}$ & Std. Error of the Estimate \\
\hline 1 & .832 & .693 & .689 & 2.81169 \\
\hline Source: Output of SPSS 20.0 & & &
\end{tabular}

Furthermore, in calculating path coefficient (e) uses e $1=\sqrt{1-R^{2}}=\sqrt{1-0.693^{2}}=0.554$. Based on calculation of path coefficient, the structural model of path analysis can be known as follows:

$\mathrm{Y}=0.185 \mathrm{X}_{1}+0.224 \mathrm{X}_{2}+0.225 \mathrm{X}_{3}+0.351 \mathrm{X}_{4}+0.554 \mathrm{e} 1$

\subsubsection{Analysis of Structural Model 2}

Analysis of structural model 2 aims to determine the effect of customer satisfaction toward customer loyalty.

\section{Table 6}

The results of analyzing the second model

\begin{tabular}{|c|c|c|c|c|c|}
\hline \multirow[t]{2}{*}{ Model 1} & \multicolumn{2}{|c|}{$\begin{array}{l}\text { Unstandardized } \\
\text { Coefficients }\end{array}$} & \multirow{2}{*}{$\begin{array}{c}\text { Standardized } \\
\text { Coefficients }\end{array}$} & \multirow[b]{2}{*}{$\mathrm{t}$} & \multirow[b]{2}{*}{ Sig. } \\
\hline & B & Std. Error & & & \\
\hline Intercept & -.400 & 1.244 & & -.322 & .748 \\
\hline Product & .171 & .051 & .167 & 3.349 & .001 \\
\hline Promotion & .232 & .054 & .235 & 4.318 & .000 \\
\hline Place & .142 & .049 & .148 & 2.916 & .004 \\
\hline Price & .228 & .058 & .230 & 3.919 & .000 \\
\hline Customer satisfaction & .164 & .069 & .153 & 2.368 & .019 \\
\hline
\end{tabular}

Source: Output of SPSS 20.0

Based on Table 3, the structural model 2 of path analysis can be written as follows:

$\mathrm{Y}=0.153 \mathrm{Y}+\mathrm{e} 2$

\section{Table 7}

Determination Coefficient 2

\begin{tabular}{lcccc}
\hline Model & $\mathrm{R}$ & $\mathrm{R}^{2}$ & Adjusted $\mathrm{R}^{2}$ & Std. Error of the Estimate \\
\hline 2 & .789 & .623 & .617 & 3.34014 \\
\hline
\end{tabular}

Source: Output of SPSS 20.0

Furthermore, in calculating path coefficient (e) uses this formula 
$\mathrm{e} 1=\sqrt{1-R^{2}}=\sqrt{1-0.623^{2}}=0.377$

Based on calculation of path coefficient, the structural model 2 of path analysis can be known as follows: $\mathrm{Y}=0.153 \mathrm{Y}+0.377 \mathrm{e} 2$

The direct effect and indirect effects using path analysis can be seen in Table 8 as follows,

Table 8

Direct effect and indirect effect

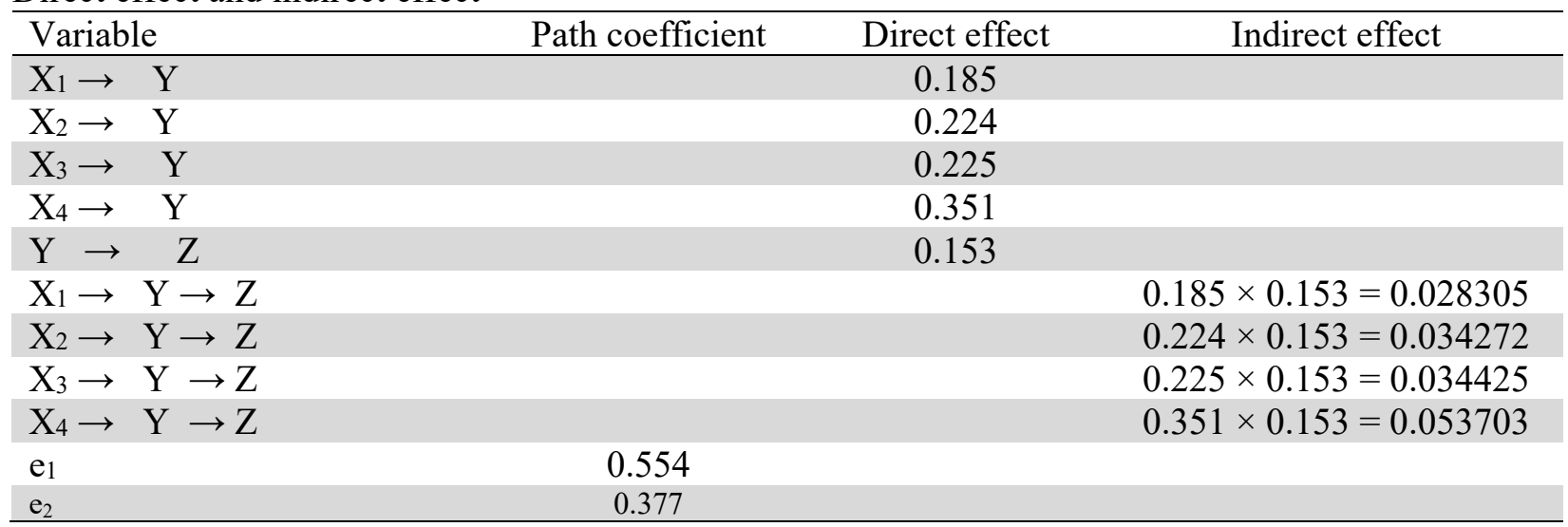

Source: primary data processed, 2018

\section{Discussion}

Based on the findings of this research, all elements of marketing mix which are product, promotion, place, and price have positive effects on customer satisfaction. For the direct effect, based on path analysis result, all marketing mix elements have positive effects on customer satisfaction. This result is in line with previous studies namely Al Muala and Al Qurneh (2012), Kadhim et al. (2016), Bawa et al. (2013), Sukamto and Lumintan (2015), Mustawadjuhaefa et al. (2017), Quang (2017), Wahab et al. (2016), Alipour et al. (2018). In addition, customer satisfaction also influences on customer loyalty in food and beverage of SMEs in Malaysia. This result is supported by previous studies such as Awan and Rehman (2014), Iqbal and Shah (2016), Ganiyu (2017) and Nguyen et al. (2018). For the indirect effect, based on Sobel test calculation, all marketing mix elements have maintained positive effects on customer loyalty through customer satisfaction in food and beverage products of SMEs in Malaysia. This result is in line with previous studies namely Quang (2017), Wahab et al. (2016), Verma and Singh (2017). Furthermore, both in direct and indirect effects, price has the most effect on customer satisfaction and customer loyalty through customer satisfaction. This is followed by place, promotion and the last is product. This means that SMEs of food and beverage products in Malaysia should give more attention on price management strategy to improve customer satisfaction and customer loyalty. SMEs need to manage more competitive and reasonable prices.

Consumers feel more satisfy with SMEs and even consumers can be loyal to SMEs if the prices offered by SMEs are able to provide the best value for money. Then for place strategy, SMEs need to review the location of the store, management of the distribution channel, and the delivery order services to consumers. The location of the store must be strategic so that consumers can buy products easily. In addition, SMEs also need to open a store in the rural region of Malaysia where the area is difficult for consumers to find local products. Next, for promotion strategy, SMEs can be more active and attractive in conducting promotional activities such as giving discounts and coupons at events in Malaysia. Besides, SMEs provide advertisements that are more informative, easy to understand and easy to attract customers to buy products. Promotion activity also must be honest so that customers would not feel disappointed. Even though the product has the lowest effect among the other three elements of marketing mix, SMEs 
still have to pay attention to effective and efficient product strategies. SMEs can produce food and beverages that are tastier and fresher. Especially regarding packaging, SMEs should make packaging more attractive than imported products. In addition, SMEs can develop innovations for local product variations. Product, promotion, place and price give contribution to customer satisfaction about $68.9 \%$ while the rest is affected by other variables which not included in this research. Moreover, customer satisfaction has a positive effect on customer loyalty. The finding also shows that product, promotion, place and price have positive effects on customer loyalty through customer satisfaction. Product, promotion, place, price and customer satisfaction give effect on customer loyalty about $61.7 \%$ and the rest is affected by other variables which not included in this research.

\section{Conclusion}

Based on the result of this research which is linked with background of the study, problem statement, research objectives and research questions, there are several things that can be concluded. For the direct effect, marketing mix elements including product, promotion, place and price have had positive effects on customer satisfaction of food and beverage products of SMEs in Malaysia. Customer satisfaction also has maintained a positive effect on customer loyalty. Moreover, for the indirect effect, marketing mix elements including product, promotion, place and price also have had positive effects on customer loyalty through customer satisfaction in food and beverage products of SMEs at Malaysia. There is a mediation effect among marketing mix elements toward customer satisfaction and customer loyalty. Price is the primary focus of customers and SMEs have to pay especial attention on this item. Not only price but also the other elements of SMEs should be improved to obtain customer satisfaction and also customer loyalty.

As further study, researchers may continue or develop this research by looking for other factors such as service quality, customer value, and so on which can affect customer satisfaction and customer loyalty. Besides, the marketing mix elements used in this research include only products, promotion, place and price whereas there are other elements such as people, physical evidence and process to be considered in other studies.

\section{Acknowledgement}

The authors would like to thank the anonymous referees for constructive comments on earlier version of this paper.

\section{References}

Alipour, M., Pour, B. M., \& Darbahaniha, A. (2018). The Effects of the 7P Marketing Mix Components on Sporting Goods Customer Satisfaction. International Journal of Business and Management Invention, 7(1), 20-26.

Adikaram, C. A. N. K., \& Khatibi, A. (2016). The relationship between customer relationship management and customer satisfaction: A study on private higher education institutions in Sri Lanka. International Journal of arts and Commerce, 5(2), 69-95.

Al Muala, A., \& Al Qurneh, M. (2012). Assessing the relationship between marketing mix and loyalty through tourists satisfaction in Jordan curative tourism. American Academic \& Scholarly Research Journal, 4(2), 1.

Albattat, A., \& Romli, S, R, M. (2017). Determining visitors' repetition by using Servqual dimensions in attraction parks: A case from Kuala Lumpur, Malaysia. International Journal of Applied Business and Economic Research, 15(15), 351-372.

Awan, A. G., \& Rehman, A. U. (2014). Impact of customer satisfaction on brand loyalty: An empirical analysis of home appliances in Pakistan. British Journal of Marketing Studies, 2(8), 18-32.

Auh, S., \& Johnson, M. D. (2005). Compatibility effects in evaluations of satisfaction and loyalty. Journal of Economic psychology, 26(1), 35-57. 
Bawa, P., Gupta, B. L., \& Sharma, B. (2013). Retail Service Quality's Impact on Value Delivery \& Customer Satisfaction in a Retail Store Environment. Journal of Marketing \& Communication, 8(4).

Department of Statistics Malaysia. (n.d.). Small \& Medium Enterprises.

Ganiyu, R. A. (2017). Customer satisfaction and loyalty: A study of interrelationships and effects in Nigerian domestic airline industry. Oradea journal of business and economics, 2(1), 7-20.

Harsono, R. (2017). The Impact of Marketing Mix (4p's) on Customer Loyalty Towards Toyota Avanza. iBuss Management, 4(1).

Iqbal, M., \& Shah, A. B. A. (2016). The impact of customer satisfaction on customer loyalty: Mediating role of customer trust. Journal of Business Management and Economic Studies, 1(1), 1-15.

Isac, F. L., \& Rusu, S. (2014). Theories of consumer's satisfaction and the operationalization of the expectation disconfirmation paradigm. Annals-Economy Series, 2, 82-88.

Išoraite, M. (2016). Marketing mix theoretical aspects. International Journal of Research Granthaalayah, 4(6), 2394-3629.

Kadhim, F. A., Abdullah, T. F., \& Abdullah, M. F. (2016). Effects of marketing mix on customer satisfaction: empirical study on tourism industry in Malaysia. International Journal of Applied Research, 2(2), 357-360.

Khadka, K., \& Maharjan, S. (2017). Customer satisfaction and customer loyalty: Case trivsel städtjänster (trivsel siivouspalvelut).

Kotler, P., Armstrong, G. M., \& Tait, M. (2010). Principles of marketing: Global and Southern African perspectives. Pearson Education South Africa.

Kotler, P., \& Keller, K, L. (2009). Marketing Management. $13^{\text {th }}$ ed. Upper Saddle River, NJ: Pearson Education, Inc.

Mustawadjuhaefa, Basrimodding, Muh.Jobhaarbima, \& Ilhamlabbase (2017). Marketing mix and service quality effect on customer satisfaction and loyalty of Toyota cars. Journal of Research in Business and Management, 5(2), 13-23.

Nguyen, H., Nguyen, H., Nguyen, N., \& Phan, A. (2018). Determinants of Customer Satisfaction and Loyalty in Vietnamese Life-Insurance Setting. Sustainability, 10(4), 1151.

Niharika (2015). Effect of marketing mix on customer satisfaction. International Journal of Science, Technology \& Management, 4(1), 73-81.

Nikhashemi, S. R., Valaei, N., \& Tarofder, A. K. (2017). Does brand personality and perceived product quality play a major role in mobile phone consumers' switching behaviour?. Global Business Review, 18(3_suppl), S108-S127.

Nuseir, M. T., \& Madanat, H. (2015). 4Ps: A strategy to secure customers' loyalty via customer satisfaction. International Journal of Marketing Studies, 7(4), 78.

Paniandi, T. A., Albattat, A. R., Bijami, M., Alexander, A., \& Balekrisnan, V. (2018). Marketing mix and destination image, case study: Batu Caves as a religious destination. Journal of Tourism, Culture and Territorial Development, 9(17), 165-186.

Pourdehghan, A. (2015). The impact of marketing mix elements on brand loyalty: A case study of mobile phone industry. Marketing and Branding Research, 2(1), 44.

Quang, N. H. (2017). Effect of Factors Marketing Mix (4P'S) on Customer Satisfaction and Loyalty to Airline in Air Cargo Transport in Vietnam's Market. International Journal of Current Research, 9(3), 47736-47742.

Diana-Rose, F., Zariyawati, M. A., Norazlina, K., Annuar, M. N., \& Manisah, O. (2016). Consumers' Purchasing Decision towards Food Products of Small and Medium Enterprises. International Review of Management and Marketing, 6(4), 836-842.

Mohd Shariff, F., Ahmad Sapawi, D., \& Wee, H. (2016). Malaysian local functional food attributes and customer satisfaction. Journal of Tourism, Hospitality \& Culinary Arts (JTHCA), 8(2), 45-54.

Salem, S., \& Chaichi, K. (2018). Investigating causes and consequences of purchase intention of luxury fashion. Management Science Letters, 8(12), 1259-1272.

Sukamto, R., \& Lumintan, D. (2015). The Impact of Marketing Mix towards Customer Loyalty Mediated by Customer Satisfaction of Blackberry Indonesia. iBuss Management, 3(2), 316-324. 
Verma, Y., \& Singh, M. R. (2017). Marketing Mix, Customer Satisfaction and Loyalty: an Empirical Study of Telecom Sector in Bhutan. Indian Journal of Commerce and Management Studies, 8(2), 121. Wahab, N. A., Hassan, L. F. A., Shahid, S. A. M., \& Maon, S. N. (2016). The relationship between marketing mix and customer loyalty in hijab industry: The mediating effect of customer satisfaction. Procedia Economics and Finance, 37, 366-371.

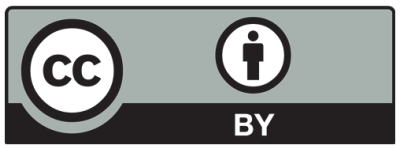

(C) 2019 by the authors; licensee Growing Science, Canada. This is an open access article distributed under the terms and conditions of the Creative Commons Attribution (CCBY) license (http://creativecommons.org/licenses/by/4.0/). 